\title{
Growth Performance, Productivity and Carbon Sequestration of Wheat (Triticum assstivum)- Shisham (Dalbergia sissoo) based Agri-silviculture System with Especial Reference to Tree Pruning Intensities and Agronomic Practices
}

\author{
Yashpal Singh*, R. C. Mishra, S. D. Upadhyaya and Aradhana Singh \\ Department of Forestry, College of Agriculture, Jabalpur, \\ Jawaharlal Nehru Krishi Vishwa Vidyalaya, Jabalpur-482004, M.P., India \\ *Corresponding author
}

\section{A B S T R A C T}

\section{Keywords}

Agrisilvicultural system, Carbon

Sequestration,

Dalbergia sissoo, wheat

Article Info

Accepted:

15 December 2019

Available Online:

20 January 2020
The experiment was carried out at Akshayvat farm, Village- Arai, Block- Karchana, Allahabad during the year 2016- 2017. In agrisilviculture system, canopy management like pruning is an essential silvicultural management practice for reducing both above and below ground competition with associated crop. The experiment consists of five pruning intensities viz: no pruning, $20 \%$ pruning, $40 \%$ pruning, $60 \%$ pruning, $80 \%$ pruning and one open condition (no tree crop only) in main plot and three levels of fertilizer doses and seed rate viz; $F_{1}$ - recommended dose of fertilizer and seed rate, $F_{2-} 25 \%$ more nitrogen then recommended dose of fertilizer and $\mathrm{F}_{3-} 25 \%$ more seed rate than recommended dose of seed in sub plot under three replications. The results revealed that wheat under open condition recorded significantly higher germination percentage $(86.30 \%)$, plant height $(64.15 \mathrm{~cm})$, number of tillers $(94.12)$, fresh wt. $(954.49 \mathrm{gm})$, dry wt.(372.19 gm), grain yield (25.03 q ha $\mathrm{h}^{-1}$ ), fixed carbon $(23.21 \%)$ and carbon sequestration $\left(4.34 .0 \mathrm{t} \mathrm{ha}^{-1}\right)$ as compared to no pruning. In different levels of fertilizer doses and seed rate maximum plant height $(64.08 \mathrm{~cm})$, number of tillers $(92.02)$, fresh wt. $(918.40 \mathrm{gm})$, dry wt.(356.77 gm), grain yield $\left(23.52 \mathrm{q} \mathrm{ha}^{-1}\right)$ and carbon sequestration $\left(3.57 \mathrm{t} \mathrm{ha}^{-1}\right)$ was significantly higher under $\mathrm{F}_{2}$ (more nitrogen than recommended dose) as compared to $F_{1}$ treatment. At age of 11 years, Dalbergia sissoo in $20 \%$ pruning gave higher tree height $(11.64 \mathrm{~m})$, basal area $\left(0.089 \mathrm{~m}^{2}\right)$, volume $\left(0.49 \mathrm{~m}^{3}\right.$ tree $\left.^{-1}\right)$, and carbon sequestration $\left(191.54 \mathrm{~kg}^{-1} \mathrm{tree}^{-1}\right)$ as compared to other treatments. In agronomical management practices, $25 \%$ more nitrogen then recommended dose $\left(\mathrm{F}_{2}\right)$ recorded significantly higher stand biomass $\left(299.03 \mathrm{~kg}\right.$ tree $\left.{ }^{-1}\right)$ over other treatments.

\section{Introduction}

Agroforestry is one of the potential options to increase tree cover outside the forest. Some of the Carbon emitted is naturally absorbed by plants during photosynthesis. Trees and plants are capable of capturing excess carbon of the atmosphere resulting in enhanced productivity. In estimating carbon sequestration, researchers accounted for 
average annual growth for different types of trees in different size classes and in different conditions (Nowak and Crane. 2002). Agroforestry provides resilience to agricultural production under current climatic variability as well as long-term climate change through intensification, diversification and buffering of trees in farming system (Schoeneberger, 2009). In agroforestry systems, two major components i.e. trees and crops are mainly responsible for $\mathrm{CO}_{2}$ sequestration. The total amount sequestrated in each component differs greatly and is dependent largely on a number of factors that includes the type of system (and the nature of components and age of plant), site quality, and previous land-use (Albrecht and Kandji 2003, Newaj and Dhyani 2008). Tree on farm can be made popular especially fast growing like sissoo which provide fodder, fuel and timber. The increasing demand and high prices of wood (fuel, timber, pulp) unlike the agriculture crops is a foremost reason for the farmers to integrate fast growing trees on their farmland in close alliance with agricultural crops (Kumar et al.,2018). Pruning of tree component is a powerful approach to regulate light, nutrients and other resource competition (Frankand Eduaro, 2003, Dhillon et al., 2010). Pruning decreased the tree taper and increases the volume and medium pruning intensity has highest volume increment (Ranietal., 2011; Manhas et al., 2011). Agroforestry is one of the solutions to increase forest area to one third of the total geographical area of the country. Wheat is widely grown winter cereal and is the backbone of food security in the world including India. It is grown in the country on an area of about 31.4 million hectares with the production of 98.38 million tones and the productivity of $32.16 \mathrm{q} / \mathrm{ha}$ (Anon., 2017). Wheat can be grown successfully in open condition and in association with Dalbergia sissoo. Agroforestry component can be a progressive method for sequestering excess carbon of the atmosphere and act as carbon sink resulting in enhanced productivity and better economic status of farmers from limited area.The agrisilviculture (tree+crop) system is more productive and sustainable than agriculture.There are many MPTS which can be used in agroforestry system, Dalbergia sissoo is one of them (Patel et al.,2017). Keeping this in view an attempt has been made to assess the performance of wheat and carbon sequestration potential under agrisilvicultural system at Akshayvat farm, Village- Arai, Block- Karchana, Allahabad U. P. India with particular reference to pruning intensities and agronomic management practices.

\section{Materials and Methods}

The experiment was laid down in Rabi during the year 2016-2017 at Akshayvat farm, Village- Arai, Block- Karchana, Allahabad to assess the performance of wheat crop and Carbon Sequestration under different Pruning Intensities and Agronomic management practices in Dalbergia sissoo - Wheat based Agrisilviculture System. Allahabad is located in the south-eastern part of Uttar Pradesh and has tropical to subtropical climate with extremes of summer and winter. During winter months especially Dec-Jan temperature drops down to as low as $5^{\circ} \mathrm{C}$ while in summer temperature reaches above $45^{\circ} \mathrm{C}$. Hot scorching wind is regular feature during the summer whereas there may be an occasional spell of frost during the winter. The annual rainfall is $1100 \mathrm{~mm}$ mostly during the monsoon autumn i.e. July-Sept with a few occasional showers during winter months. Soil of this region is sandy loam and slightly alkaline. The experiment was conducted during rabi season under 11years old Dalbergia sissoo during 2003. Dalbergia sissoo was planted in $5 \times 5 \mathrm{~m}$ spacing. The treatment combinations involved five pruning treatments (viz., no pruning, 20\%, 40\%, 60\% 
and $80 \%$ pruning from ground level) and one open (crop alone) in main plot and three fertilizer doses viz. F1-Recommended dose of fertilizer (120:60:40 NPK kg ha-1) + Seed rate (80kgha-1), F2- F1+25\% more nitrogen than recommended dose and $\mathrm{F} 3-\mathrm{F} 1+25 \%$ more seed rate than recommended dose in sub plot. Wheat variety GW 173 was sown in sub plots at $20 \mathrm{~cm}$ spacing. All the observations on crop were recorded before harvesting and at the time of harvesting. Tree observations were also recorded. The crop and tree parameter were analyzed statistically using analysis of variance for strip plot design with three replications. The significance was tested for all the parameters at 5\% level.

\section{Results and Discussion}

\section{Growth and yield parameters of wheat crop}

\section{Effect of pruning intensities}

The growth parameters viz., plant height and number of tillers $\mathrm{m}^{-2}$ fresh and dry weight were recorded at harvest stage (Table 1). Effect of different pruning intensities in D. sissoo produced significant effect on plant height (cm),number of tillers/MRL, fresh weight(gm), dry weight (gm), grain yield (q $\mathrm{ha}^{-1}$ ) at harvest. Plant under open condition i.e. crop without tree recorded significantly the tallest plant $(64.15 \mathrm{~cm})$, maximum number of tillers/MRL (94.12), highest fresh weight (954.49 gm), dry weight (372.19 gm) and grain yield (25.03 q ha-1). Among pruning intensities (no pruning, 20\%, 40\%, 60\% and $80 \%$ pruning), $80 \%$ pruning recorded significantly tallest plant height $(63.68 \mathrm{~cm})$, number of tillers/MRL (94.12), fresh weight (938.68 gm), dry (364.34 gm) and grain yield $\left(23.60 \mathrm{q} \mathrm{ha}^{-1}\right)$ of wheat whereas no pruning recorded significantly shorter plant height (62.12 cm),number of tillers/MRL (85.34), fresh weight $(864.90 \mathrm{gm})$, dry weight $(317.03$ gm), grain yield $\left(20.05 \mathrm{q} \mathrm{ha}^{-1}\right)$ at harvest.
Dropplemann and Berliner (2003) also recorded the same results in agroforestry system.

\section{Effect of agronomical management practices}

During the study period it was observed that, $\mathrm{F}_{2}-25 \%$ more nitrogen than recommended dose of fertilizer and seed rate recorded significantly maximum plant height (64.08 $\mathrm{cm}$ ), number of tillers/MRL (92.02), dry weight (356.77 gm) and grain yield (23.52 q $\left.\mathrm{ha}^{-1}\right)$ at harvest. However lowest plant height $(62.73 \mathrm{~cm})$, number of tillers/MRL (89.05), dry weight (338.99 gm) and grain yield $\left(21.51 \mathrm{q} \mathrm{ha} \mathrm{ha}^{-1}\right)$ was observed in $\mathrm{F}_{1^{-}}$ recommended dose of fertilizer and seed rate (Table 1). Ray and Mishra (1999) also recorded the same results.

\section{Carbon sequestration by the crop (wheat)}

In agroforestry systems, although tree sequester more carbon, but crops also fix and store carbon in considerable amounts. Wheat under open condition recorded significantly highest fixed carbon (23.21\%) and carbon sequestration (4.34 t/ha), whereas wheat under no pruning recorded significantly lowest fixed carbon (20.92\%) and carbon sequestration (3.33 t/ha). Different pruning intensities showed no significant difference on fixed carbon. Crop sown under Dalbergia sissoo, the fresh weight (938.68 gm) and dry weight of wheat (364.34 gm) and carbon sequestration $(4.11 \mathrm{t} / \mathrm{ha})$ were significantly higher in the crop sown under $80 \%$ pruned Dalbergia sissoo trees and fresh weight, dry weight and carbon sequestered was at par in the crop under $60 \%$ and $40 \%$ pruned trees. The ash content $(16.85 \%)$ of the crop was significantly higher in the crop under $60 \%$ pruned trees and varied significantly from open crop. Moisture content was significantly highest $(63.35 \%)$ under no pruning and lowest 
value $(61.00 \%)$ for Moisture content was observed under open condition.

Different levels of fertilizer dose and seed rate show significant effect on ash content and fixed carbon. $\mathrm{F}_{2}$ i.e. $25 \%$ more nitrogen than recommended dose recorded significantly maximum ash content $(16.81 \%)$ as compared to $F_{1}$ (i.e. recommended dose of seed rate and fertilizer dose) and $\mathrm{F}_{3}$ (i.e. $\mathrm{T}_{1}+25 \%$ more seed rate than recommended dose).

\section{Tree (Shisam) growth parameter}

Effect of pruning intensities and agronomical management practices

In Dalbergia sissoo $20 \%$ pruning recorded significantly higher plant height $(11.64 \mathrm{~m})$, basal area $\left(0.089 \mathrm{~m}^{2}\right)$, tree volume $(0.49$ $\mathrm{m}^{3} /$ tree), while $80 \%$ pruning recorded significantly lower plant height $(9.45 \mathrm{~m})$, basal area $\left(0.041 \mathrm{~m}^{2}\right)$, tree volume $(0.30$ $\mathrm{m}^{3} /$ tree), also no pruining recorded significantly higher dbh $(23.60 \mathrm{~cm})$ which was at par $(23.46 \mathrm{~cm})$ with $20 \%$ pruning treaetment while $80 \%$ pruning recorded significantly lower dbh $(16.42 \mathrm{~cm})$.

The probable reason of lower dbh value in $80 \%$ pruning may be due to heavy pruning leads to greater removal of leaf area than light pruning and strongly reduce the overall carbohydrate production of a tree. This implies that pruning reduces both the production and the consumption of the carbohydrates, which affect the tree growth adversely (Bredenkamp et al., 1980). In the present study, tree growth interms of $\mathrm{dbh}$, height and crown diameter was lowest in $80 \%$ pruning and increased with reduced pruning intensities.
Different levels of fertilizer and seed rate did not have significant variations for any of the above parameters recorded.

\section{Carbon Sequestration by trees}

In Dalbergia sissoo the above ground biomass (364.50 kg/tree), was significantly maximum in no pruining which was at par with $20 \%$ (361.38 kg/tree) and 40\% (346.25 kg/tree) pruned trees. Carbon sequestration in the tree (76.62 $\mathrm{t} \mathrm{ha}^{-1}$ ) was significantly higher in $20 \%$ pruned trees which was at par with no pruning and $40 \%$ pruned trees while lowest value (36.20 $\mathrm{t} \mathrm{ha}^{-1}$ ) of Carbon sequestration was reported in $80 \%$ pruning intensity. Carbon-dioxide sequestrated in the tree $(702.96 \mathrm{~kg} /$ tree $)$ and Carbon-di-oxide sequestrated in the tree per year $(63.91 \mathrm{~kg} /$ tree/year) was significantly higher in $20 \%$ pruned trees and at par with unprimed and $40 \%$ pruned trees.

Different levels of fertilizer and seed rate did not have significant variations for any of the above parameters recorded.

\section{Carbon sequestration of agrisilviculture system $\left(\right.$ t ha $\left.^{-1}\right)$}

The study (1\&2) revealed that carbon sequestration was significantly higher under managed agro forestry system. 20\% pruned Dalbergia sissoo sequestered maximum carbon and was at par unpruned trees and $40 \%$ pruned trees. The values of Carbon sequestration were significantly minimum in $80 \%$ pruned trees. Different level of fertilizer and seed rate showed no significant effect on carbon sequestration. The carbon sequestration value was significant maximum in open (crop alone). 
Table.1 Performance of wheat crop under Dalbergia sissoo based agri-silviculture system with special reference to pruning intensities and agronomic management practices

\begin{tabular}{|c|c|c|c|c|c|c|c|c|c|}
\hline Treatment & $\begin{array}{l}\text { Plant ht. } \\
\quad(\mathrm{cm})\end{array}$ & $\begin{array}{l}\text { No. of } \\
\text { tillers } \\
\text { / MRL }\end{array}$ & $\begin{array}{c}\text { Fresh } \\
\text { wt. of } \\
\text { Wheat } \\
\text { (gm) }\end{array}$ & $\begin{array}{l}\text { Dry wt. } \\
\text { of Wheat } \\
\text { (gm) }\end{array}$ & $\underset{\left.\text { ha }^{-1}\right)}{\underset{\text { Grain }}{\text { Gield }}}(\mathbf{q}$ & $\begin{array}{l}\text { Moisture } \\
\text { content } \\
(\%)\end{array}$ & $\begin{array}{c}\text { Ash } \\
\text { content } \\
(\%)\end{array}$ & $\begin{array}{l}\text { Fixed } \\
\text { carbon } \\
(\%)\end{array}$ & $\begin{array}{c}\text { Carbon } \\
\text { sequest } \\
\text { (t ha } \\
\end{array}$ \\
\hline \multicolumn{10}{|c|}{ Pruning intensities } \\
\hline$P_{0}-$ No pruning & 62.12 & 85.34 & 864.90 & 317.03 & 20.05 & 63.35 & 15.73 & 20.92 & 3.33 \\
\hline $\begin{array}{c}P_{1}-20 \% \\
\text { pruning }\end{array}$ & 62.83 & 88.66 & 898.73 & 335.82 & 21.06 & 62.62 & 15.99 & 21.39 & 3.60 \\
\hline $\begin{array}{c}P_{2}-40 \% \\
\text { pruning }\end{array}$ & 62.37 & 89.81 & 910.46 & 349.51 & 22.08 & 61.59 & 16.74 & 21.67 & 3.79 \\
\hline $\begin{array}{c}P_{3}-60 \% \\
\text { pruning }\end{array}$ & 63.52 & 90.24 & 914.88 & 352.52 & 22.84 & 61.46 & 16.85 & 21.69 & 3.83 \\
\hline $\begin{array}{c}P_{4}-80 \% \\
\text { pruning }\end{array}$ & 63.68 & 92.57 & 938.68 & 364.34 & 23.60 & 61.18 & 16.29 & 22.53 & 4.11 \\
\hline $\begin{array}{c}\text { Open } \\
\text { ( crop alone) }\end{array}$ & 64.15 & 94.12 & 954.49 & 372.19 & 25.03 & 61.00 & 15.79 & 23.21 & 4.34 \\
\hline SEM \pm & 0.16 & 0.12 & 1.75 & 3.6 & 0.219 & 0.39 & 0.11 & 0.38 & 0.11 \\
\hline $\mathrm{CD}(\mathrm{P}=0.05)$ & 0.50 & 0.38 & 5.50 & 11.34 & 0.690 & 1.22 & 0.34 & 1.21 & 0.35 \\
\hline \multicolumn{10}{|c|}{ Agronomical Management } \\
\hline $\begin{array}{c}F_{1}-\text { Recommended } \\
\text { dose of fertilizer \& } \\
\text { seed rate) }\end{array}$ & 62.73 & 89.05 & 909.92 & 338.99 & 21.51 & 62.79 & 15.50 & 21.72 & 3.70 \\
\hline $\begin{array}{c}\mathrm{F}_{2}-\mathrm{F}_{1}+25 \% \text { more } \\
\text { nitrogen than } \\
\text { recommended dose }\end{array}$ & 64.08 & 92.02 & 918.40 & 356.77 & 23.52 & 61.13 & 16.81 & 22.06 & 3.94 \\
\hline $\begin{array}{c}\mathrm{F}_{3}-\mathrm{F}_{1}+25 \% \text { more } \\
\text { seed rate than } \\
\text { recommended dose }\end{array}$ & 63.03 & 89.30 & 912.75 & 349.95 & 22.30 & 61.68 & 16.39 & 21.93 & 3.86 \\
\hline SEM \pm & 0.13 & 0.19 & 13.62 & 2.8 & 0.328 & 0.35 & 0.03 & 0.37 & 0.06 \\
\hline $\mathrm{CD}(\mathrm{P}=0.05)$ & 0.49 & 0.73 & 53.46 & 11.05 & 1.288 & 1.37 & 0.12 & 1.45 & 0.23 \\
\hline
\end{tabular}

MRL- Meter Row Length 
Table.2 Tree growth parameters and Carbon Sequestration of Dalbergia sissoo as influenced by different pruning intensities and agronomical practices in agri-silviculture system

\begin{tabular}{|c|c|c|c|c|c|c|c|c|c|}
\hline Treatment & $\begin{array}{l}\text { Tree } \\
\text { ht. } \\
\text { (m) }\end{array}$ & $\begin{array}{l}\text { dbh } \\
(\mathrm{cm})\end{array}$ & $\begin{array}{c}\text { Basal } \\
\text { Area } \\
\left(\mathbf{m}^{2}\right)\end{array}$ & $\begin{array}{c}\text { Tree } \\
\text { volume } \\
\left(\mathbf{m}^{3} /\right. \\
\text { tree }))\end{array}$ & $\begin{array}{l}\text { Above } \\
\text { ground } \\
\text { biomass } \\
\text { (kg/tree) }\end{array}$ & $\begin{array}{c}\text { Fixed } \\
\text { carbo } \\
\text { n } \%\end{array}$ & $\begin{array}{c}\text { Carbon } \\
\text { Sequest. } \\
\text { Potentia } \\
\text { l } \\
\left(\mathrm{t} \text { ha }^{-1}\right)\end{array}$ & $\begin{array}{c}\mathrm{CO}_{2} \\
\text { Sequst. } \\
\text { (kg/ } \\
\text { tree) }\end{array}$ & $\begin{array}{c}\mathrm{CO}_{2} \\
\text { Sequst. } \\
\text { (kg/Tree/ } \\
\text { year) }\end{array}$ \\
\hline \multicolumn{10}{|c|}{ Pruning intensities } \\
\hline$P_{0}-$ No pruning & 10.23 & 23.60 & 0.086 & 0.47 & 364.50 & 51.83 & 73.77 & 676.81 & 61.53 \\
\hline$P_{1}-20 \%$ pruning & 11.64 & 23.46 & 0.089 & 0.49 & 361.38 & 52.13 & 76.62 & 702.96 & 63.91 \\
\hline$P_{2}-40 \%$ pruning & 11.03 & 22.29 & 0.078 & 0.46 & 346.25 & 53.13 & 72.78 & 667.79 & 60.71 \\
\hline$P_{3}-60 \%$ pruning & 9.93 & 16.92 & 0.046 & 0.32 & 177.79 & 52.79 & 37.53 & 344.37 & 31.31 \\
\hline $\mathrm{P}_{4}-80 \%$ pruning & 9.45 & 16.42 & 0.041 & 0.30 & 173.63 & 53.33 & 36.20 & 332.14 & 30.19 \\
\hline SEM \pm & 0.46 & 0.34 & 0.01 & 0.06 & 10.82 & 0.65 & 2.01 & 18.48 & 1.68 \\
\hline $\mathrm{CD}(\mathrm{P}=0.05)$ & 1.51 & 1.09 & 0.04 & 0.18 & 35.29 & 2.13 & 6.57 & 60.26 & 5.48 \\
\hline \multicolumn{10}{|c|}{ Agronomical Management } \\
\hline $\begin{array}{c}F_{1}-\text { Recommended } \\
\text { dose of fertilizer \& } \\
\text { seed rate) }\end{array}$ & 10.85 & 19.73 & 0.066 & 0.36 & 275.50 & 52.60 & 58.40 & 535.82 & 48.71 \\
\hline $\begin{array}{c}\mathrm{F}_{2}-\mathrm{F}_{1}+25 \% \text { more } \\
\text { nitrogen than } \\
\text { recommended dose }\end{array}$ & 10.54 & 21.32 & 0.069 & 0.44 & 299.03 & 53.13 & 60.52 & 555.27 & 50.48 \\
\hline $\begin{array}{l}\mathrm{F}_{3}-\mathrm{F}_{1}+25 \% \text { more } \\
\text { seed rate than } \\
\text { recommended dose }\end{array}$ & 10.31 & 20.45 & 0.067 & 0.44 & 283.50 & 52.70 & 60.77 & 557.60 & 50.69 \\
\hline Tree alone & 10.13 & 20.64 & 0.069 & 0.40 & 280.80 & 52.13 & 57.83 & 530.56 & 48.23 \\
\hline SEM \pm & 0.20 & 0.65 & 0.002 & 0.04 & 4.598 & 0.69 & 1.05 & 9.70 & 0.88 \\
\hline $\mathrm{CD}(\mathrm{P}=0.05)$ & 0.70 & 2.26 & 0.006 & 0.15 & 15.89 & 2.37 & 3.66 & 33.55 & 3.05 \\
\hline
\end{tabular}


Fig.1

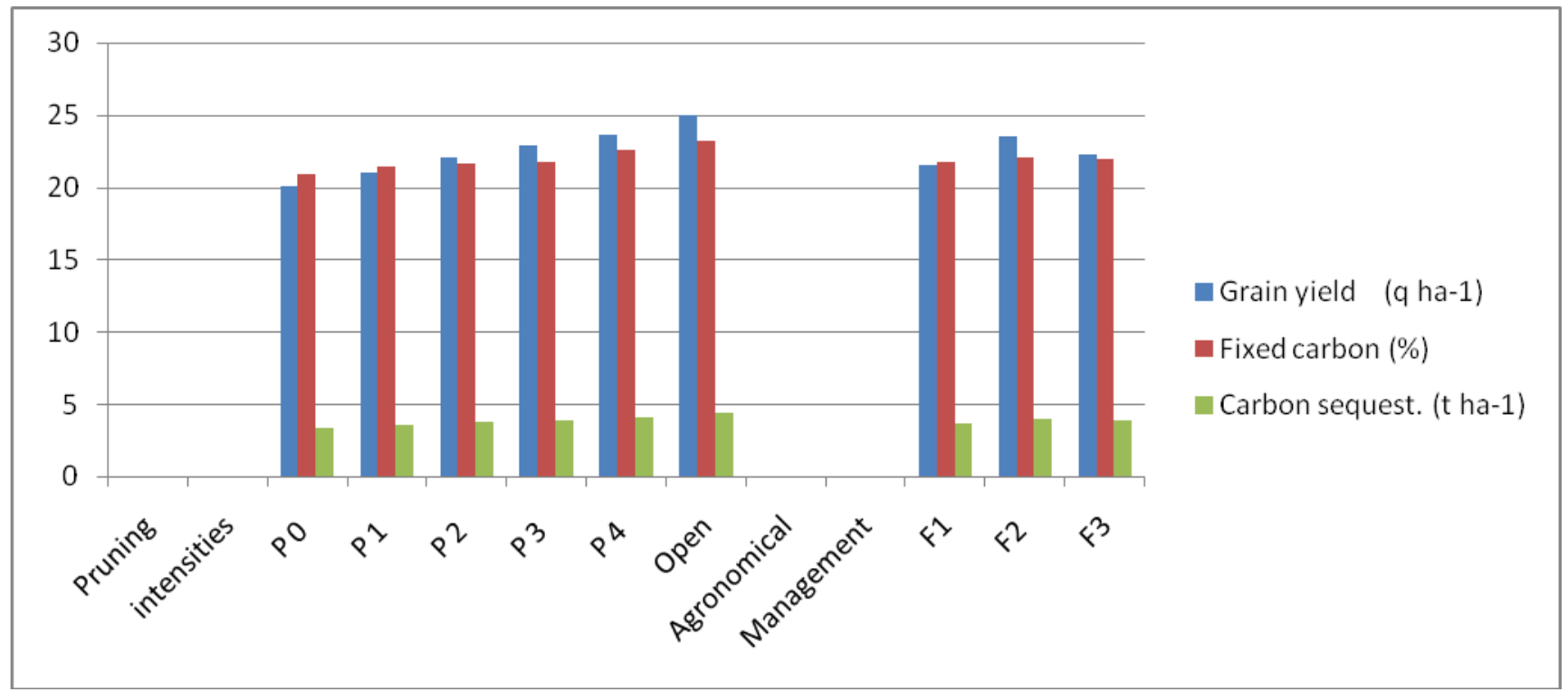

Fig.2

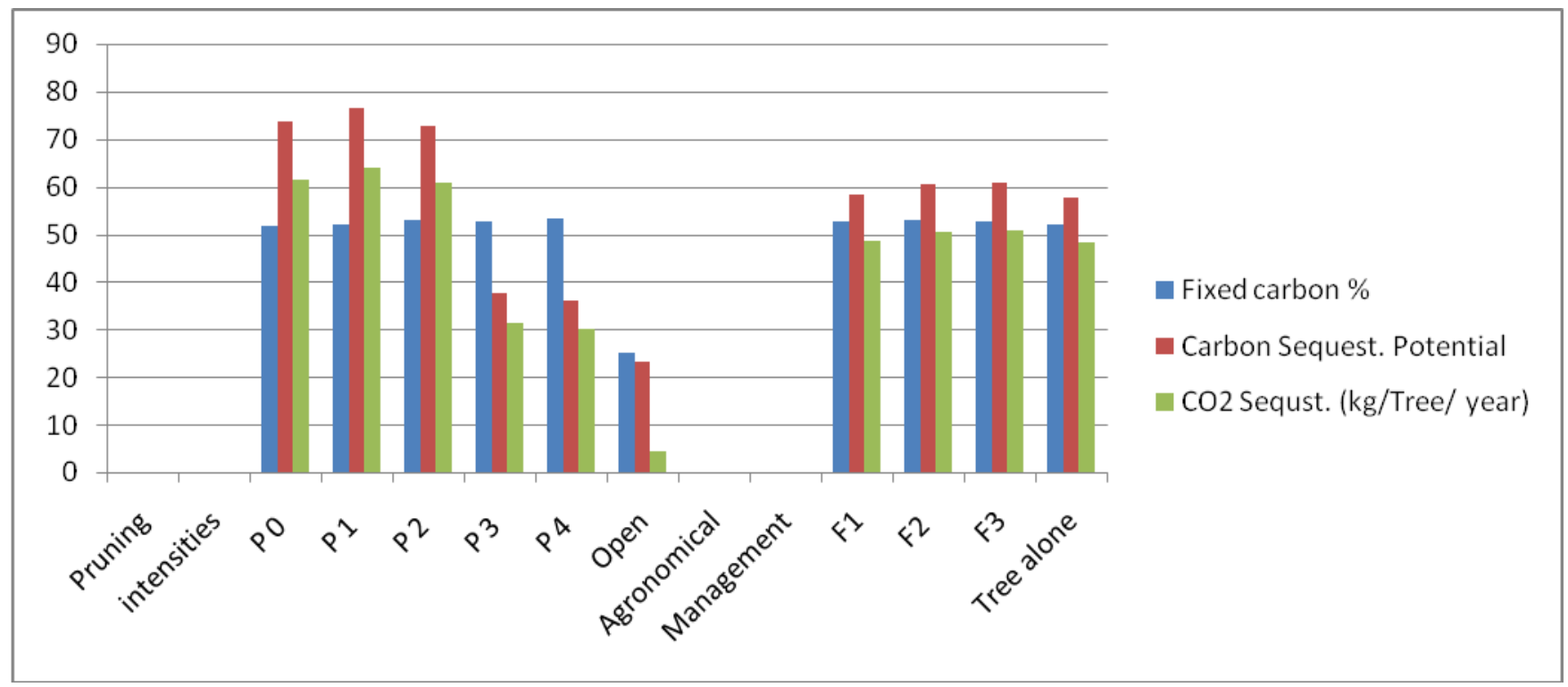

Wheat + Dalbergia sissoo (20\% pruned) recorded significantly higher carbon sequestration (76.62 $\mathrm{t} \mathrm{ha}^{-1}$ ) as compared to other pruning treatment, tree alone $\left(57.83 \mathrm{t} \mathrm{ha}^{-}\right.$ ${ }^{1}$ ) and crop alone (4.34 $\left.\mathrm{t} \mathrm{ha}^{-1}\right)$ which recorded the lower carbon sequestration under agrisilviculture system. The productivity performance of wheat crop grown under Shisham is less as compared to open but the substantial loss in yield can be compensated by the trees in terms of economics and carbon sequestration with particular reference to carbon conservation and climate change mitigation.

\section{Acknowledgements}

The author is grateful to the director, CAFRI, 
Agro forestry, Jhansi, and Scientist of SFRI and TFRI, Jabalpur for providing necessary facilities, utilization for encouragement and valuables suggestions.

\section{References}

Albrecht A and Kandji ST 2003.Carbon sequestration in tropical agroforestry systems. Agriculture, Ecosystems and Environment. 99:15-27

Anonymous.(2017). Annual Report. Department of Agriculture and Cooperation and Farmer Welfare, Government of India, New Delhi. 9.

Bredenkamp, B.V., Malan, F.S., Conradie, W.E.,1980.Some effects of pruning on growth and timber quality of Eucalyptus grandis in Zuzuland. South African Forestry Journal 114, 29-34.

Dhillon, W.S., Srinidhi, H.V., Chauhan, S.K., Singh, C.,Singh, N.,Jabeen, N.,2010. Micro-envoriment and physiology of turmeric cultivated under poplar tree canopy. Indian Journal of Agroforestery,12(2), 23-37.

Dropplemann, K., Berliner, P., 2003. Runoff agroforestry-a technique to secure the livelihood of pastoralists in the Middle East. Journal of Arid Environments 54, 571-577.

Frank, E., Eduardo, S., 2003. Biomass dynamics of Erythrinalanceolata as influenced by shoot pruning intensity in Costa Rica. Agroforestry
System57,19-28.

Kumar, V., Jain, K.K., Kumar, S., and Kumhar, B.L., Impact of Pruning Intensity on Tree Biomass Production of Dalbergia sissoo Roxb and Fresh Yield of Turmeric, Int. J. Pure App. Biosci. 6(3): 191-195 (2018).

Manhas, S.S.,Gill, B.S.,Sharma, Sushil and Kumar, Krishan., 2011. Effect of pruning material, planting dates and harvesting dates on growth, yield and quality of turmeric. Indian Journal of Horticulture 689(2), 229-234.

Newaj R and Dhyani SK 2008. Agroforestry for carbon sequestration: Scope and present status. Indian journal of agroforestry 10:1-9.

Nowak DJ and Crane DE 2002. Carbon storage and sequestration by urban trees in the USA. Envir. Pollution 116: 381-389.

Patel Sudha, Bisen Neelam, Jain KK and Rahangdale CP. 2017. International Journal of Bio-resource and Stress Management 8(3):418-423

Ray, D.K., Mishra, S.S., 1999. Effect of weed management in direct seeded upland rice at varying nitrogen levels. Indian Journal of Agronomy 44(1), 105-108

Schoeneberger MM 2009. Agro forestry : working trees for sequestering carbon on agricultural lands. Agroforest. Syst. 75:27-37.

\section{How to cite this article:}

Yashpal Singh, R. C. Mishra, S. D. Upadhyaya and Aradhana Singh. 2020. Growth Performance, Productivity and Carbon Sequestration of Wheat (Triticum assstivum)- Shisham (Dalbergia sissoo) based Agri-silviculture System with Especial Reference to Tree Pruning Intensities and Agronomic Practices. Int.J.Curr.Microbiol.App.Sci. 9(01): 406-413. doi: https://doi.org/10.20546/ijcmas.2020.901.044 